DOI: $10.17805 /$ zpu.2019.3.9

\title{
Репрезентация гендерных режимов рабочего класса в биографических нарративах молодежи
}

\author{
Т. В. ГАВРИЛЮК
}

ТЮМЕНСКИЙ ИНДУСТРИАЛЬНЫЙ УНИВЕРСИТЕТ

В статье обоснована необходимость актуализации исследования гендерного неравенства с учетом классового статуса, рассмотрены существующие в повседневной культуре рабочего класса современной России гендерные режимы путем анализа их репрезентации в биографических нарративах молодежи. В фокусе внимания находятся межпоколенная трансляция гендерных нормативных паттернов, микрополитики власти и доминирования в рабочих семьях, формы их дискурсивного производства и легитимации. Эмпирическая база исследования представлена 31 биографическим интервью с представителями нового рабочего класса в возрасте от 21 до 33 лет, проживающими в г. Тюмени и занятыми в сфере промышленности, технического обслуживания и клиентского сервиса. Интервью проводились с февраля по август 2018 г., в качестве основных исследовательских инструментов были использованы рефлексивный анализ, базирующийся на категориальном поле феноменологии и социального конструктивизма, а также кодирование и квантификация данных.

* Статья выполнена при финансовой поддержке гранта РНФ № 17-78-20062 «Жизненные стратегии молодежи нового рабочего класса современной России» 
Было установлено, что нормативный паттерн мужчины-добытчика, обладающего властью в семье на основании контроля над экономическими ресурсами, по-прежнему является доминирующим среди российских юношей, однако их жизненный опыт и опыт родительских семей в большинстве случаев не соответствуют идеально-типической конструкции доминирующего гендерного порядка. Девушки из сервисного сектора также стремятся к патриархальной модели семьи, демонстрируя желание закрепиться на позиции среднего класса посредством удачного замужества. Путем изучения гендерных режимов родительских семей информантов было обнаружено, что финансовое и статусное доминирование мужчины не вызывает сомнений в его лидерстве. Когда женщина занимает более высокую статусную позицию или играет решающую роль в обеспечении семьи, информанты склонны говорить о «равноправии» в семье. В семьях с матриархальным режимом ситуация женского лидерства оцениваются как вынужденная. В смысловых структурах жизненного мира рабочей молодежи России женщина не может играть роль лидера, ее задачей становится умелая игра в семейной властной микрополитике, направленная на сохранение видимости традиционного или эгалитарного гендерного порядка.

Ключевые слова: рабочий класс; молодежь; молодежь рабочего класса; патриархат; гендер; гендерный режим; гендерное неравенство

\section{ВВЕАЕНИЕ}

Гендерная проблематика долгое время оставалась на периферии классового анали1 за, однако динамика социальных процессов в трудовой и семейной сфере заставила переосмыслить позиции женщин в социальной структуре. Аеиндустриализация развитых западных стран обусловила проблематизацию традиционных критериев маскулинности рабочего класса и оснований мужского доминирования. В современной российской социологии в силу неразработанности классового подхода взаимопересечение гендерных и классовых характеристик в анализе различных аспектов социальной жизни встречается лишь в единичных работах (Vanke, 2014; Pro тело ..., 2013), хотя имеется задел ранних исследований в русле классического марксизма-ленинизма, обращающихся к гендерной проблематике (Вольфсон, 1929).

В данной статье обоснована необходимость актуализации исследования гендерного неравенства с учетом классового статуса, рассмотрены существующие в повседневной культуре рабочего класса современной России гендерные режимы путем анализа их репрезентации в биографических нарративах молодежи. В фокусе внимания находятся межпоколенная трансляция гендерных нормативных паттернов, микрополитики власти и доминирования в рабочих семьях, формы их дискурсивного производства и легитимации. Источниковая база исследования представлена 31 биографическим интервью с представителями нового рабочего класса в возрасте от 21 до 33 лет, проживающих в г. Тюмени и занятых в сфере промышленности, технического обслуживания и клиентского сервиса. Интервью проводились с февраля по август 2018 г., в качестве основных исследовательских инструментов были использованы рефлексивный анализ, базирующийся на категориальном поле феноменологии и социального конструктивизма, а также кодирование и квантификация данных.

\section{ОБЗОР АИТЕРАТУРЫ}

В период концептуального доминирования структурного функционализма гендерное неравенство не рассматривалось в качестве релевантного критерия классового анализа. Статусная позиция женщины в классовой структуре выступала в качестве производной социальной позиции ее мужа или отца, при этом подчиненное положение и отсутствие автономии трактовались как функциональные для социальной си- 
стемы (Парсонс, 2002). Уже в 1960-е гг. подобный унифицирующий подход был подвергнут критике представителями ранней феминистской теории, однако в целом структурно-функциональный подход с его невниманием к гендерному неравенству оставался доминирующим в классовом анализе вплоть до 1980-х годов (Goldthorpe, 1983). В 1980-е годы левоориентированный феминизм обозначил новые теоретические вызовы. Рассматривая домашний труд женщины как форму эксплуатации со стороны мужа, его представители аргументировали невозможность аналитического уравнивания их классового статуса (Delphy, 1984: 38-39). В научный оборот вводится категория «кросс-классовых» семей, изначально базирующаяся на критерии профессиональной принадлежности и вида исполняемого труда (Britten, Heath, 1983).

Экономическая эмансипация женщин, трансформировавшая сферу семейно-брачных отношений, возрастающее внимание к индивидуальным аспектам жизненного опыта представителей различных классов привели к постепенному отказу от конвенциального подхода. В современных реалиях каждый человек рассматривается как автономная единица классовой структуры, вне зависимости от его гендерной принадлежности или семейного положения, а фокус внимания смещается от споров о критериях классовой дифференциации к анализу реальных различий образа жизни, порожденных социальным неравенством (Гаврилюк, 2018).

В актуальном дискурсе гендерная и классовая проблематика интегрируются в рамках исследований жизненного пути ("life course studies”). Аля этого поля характерен макросоциологический ракурс анализа, при котором индивидуальный жизненный путь выступает в качестве производной структурных возможностей и ограничений, существующих в рассматриваемый исторический период (Augustyn, Jackson, 2017). Большинство современных авторов исходит из допущения о значительных различиях образа жизни и гендерных нормативных паттернов представителей среднего и рабочего класса (Meier, Allen, 2008; Penman-Aguilar et al., 2013). Наиболее актуальной концептуальной схемой, специфицирующей взаимоналожение классовой и гендерной дискриминации, является теория интерсекциональности. Интерсекциональный ракурс анализа предполагает негативную дефиницию идентичности, маргинализированной одновременно по нескольким основаниям в рамках исторически сложившихся систем доминирования, таких как патриархат, сексизм, классовая эксплуатация, эйджизм, расизм, колониализм и гетеронормативность (Гаврилюк, Бочаров, 2018).

Апелляция к общепринятым объяснительным конструктам, таким как раса, гендер, класс и влияние социальных институтов, тем не менее не проясняла значение индивидуального волевого акта, различия индивидуальных способностей и прикладываемых усилий в достижении цели, не давала возможности раскрыть механизм осуществления значимых выборов, что обусловило необходимость сближения поля "life course studies” и биографического подхода. Снятие концептуального напряжения между теориями структуры и агентности позволило использовать понятие биографии для исследования процесса социального конструирования жизни в пределах институционально заданных параметров (Falk, Weymann, 2002: 502). Ряд авторов артикулировали необходимость герменевтической перспективы в исследованиях жизненного пути с целью выявления и понимания субъективных смыслов, вкладываемых в процессы значимых ролевых переходов представителями разных возрастных когорт (Bird, Kruger, 2005: 188-189). Подобный ракурс анализа представляется релевантным для исследования гендерных режимов культуры рабочего класса. 


\section{МЕТОДОАОГИЯ, ЦЕАИ И ЭМПИРИЧЕСКАЯ БАЗА \\ ИССАЕАОВАНИЯ}

Анализ актуальных отечественных и зарубежных подходов к исследованию жизненной динамики демонстрирует целесообразность использования методологического подхода «агентности внутри структуры» (Р. Сеттерстен и $\Lambda$. Ганнон), позволяющего сочетать холистский алгоритмический подход, рассматривающий жизненный путь как организованную целостность в рамках структурно заданных параметров, и герменевтическую перспективу в исследовании биографии как совокупности конкретных событий, способов их легитимации и рефлексии молодыми людьми рабочего класса (Settersten, Gannon, 2005). Совмещение подходов предоставляет возможность осуществить глубокий социологический анализ взаимосвязи макросоциальных и личностных аспектов фреймирования гендерных режимов, взглянуть как на структурные факторы, их формирующие, так и на многочисленные аффективные потоки, порожденные конкретными ситуациями социального взаимодействия.

В данной статье путем анализа биографических нарративов мы обратимся к тому, как гендерные конструкты производятся, транслируются и меняются в повседневных практиках, формируя определенный гендерный режим. Будут рассмотрены следующие проблемы:

- доминирующие гендерные установки в культуре молодежи рабочего класса, их основания и средства дискурсивного производства в нарративах информантов;

- воспроизводство и трансформация гендерного режима в культуре российского рабочего класса на основе межпоколенного анализа (легитимация гендерного режима в родительской семье; влияние интернализированных в детстве установок на конструирование представлений информанта о маскулиности и феминности);

Эмпирическая база исследования представлена биографическими интервью длительностью от 40 минут до 2,5 часа. Критерием отбора информантов являлась их принадлежность к новому рабочему классу, под которым мы понимаем группу наемных работников, занятых во всех сферах материального производства и сервиса, труд которых рутинизирован, разделен на стандартизированные сегменты, поддается алгоритмизации и количественному нормированию результатов; не участвующих в управлении и не имеющих прав собственности в организации, в которой они трудятся. Интервью проводились с февраля по август 2018 г., всего был опрошен 31 информант, проживающий в г. Тюмени: из них 21 мужчина -14 человек, занятых в сфере «традиционных» рабочих профессий (промышленность, строительство, ремонт, техническое обслуживание, добыча полезных ископаемых), и 7 человек, занятых в сервисной сфере (торговля и другие виды клиентского обслуживания), и 10 женщин, занятых в сервисной сфере. Аля исследования были отобраны блоки интервью, включающие дискурсы о взаимоотношениях в родительской семье, а также о собственной семье информанта, существующей или планируемой. В качестве основного исследовательского инструмента использован рефлексивный анализ, базирующийся на категориальном поле феноменологии и социального конструктивизма, а также кодирование и квантификация данных.

\section{РЕЗУАЬТАТЫ ИССАЕАОВАНИЯ}

Аля информантов-мужчин как из промышленного, так и из сервисного сектора ценностным ориентиром является традиционный паттерн «добытчика». Подчеркивая ответственность мужчины за благополучие семьи, они связывают готовность 
к ее созданию с такими факторами, как социальная нормативность, включающая «правильный» возраст, стабильная работа и достаточный для обеспечения жены и детей доход.

Николай, 29 лет, автомеханик, в гражданском браке два года: «Уже мне пора. Через два дня 30 лет исполнится... Я планирую оформить отношения и ребенка родить в ближайший год».

Виталий, 22 год, охранник, не женат: «О семье я еще не задумььвался и не буду задумываться до тех пор, пока сам не встану на ноги крепко. Вопрос в другом. Тут надо подумать, сможешь ты обеспечить ребенка, чтобы не было такого, что батя спился, мать пропала, ребенок в детдоме. Надо знать, ито ть сможешь это выъезти финансово, физически. Я не могу, например, это сделать. В моей ситуачии, если я уделю время семье, я потерял деньги».

В высказывании Амитрия, 21 год, техника по радионавигации (не женат, есть девушка), помимо вышеуказанных параметров готовности к браку, находит отражение один из вариантов гендерной нормативности нашего общества относительно возраста вступления в брак - мужчине нет оснований торопиться, так как он способен завести семью с молодой женщиной и стать отцом в любой период своего жизненного пути при условии финансового благополучия: «Идеального возраста нету, есть положение твое финансовое... Ть можешь и в 18 лет женитьсл, если имеешь хорошую работу... Еще большую роль играет ответственность. То есть даже если человек будет хорошо зарабатььать, но он будет безответственньй, то девушка тоже должна смотреть и как бь понимать, что какая с ним может бьть семья... Так что я считаю, самое главное - это положение. Можно и до 50 лет не иметь семьи, а потом сразу, бач, жениться, и трое детей, жена молодая, красавииа». Утверждение одного из первых исследователей маскулинности рабочего класса А. Толсона, относящееся к концу 1970-х гг., таким образом, не потеряло актуальности и по-прежнему выражается в коллективных установках рабочей молодежи: «B нашем обществе основной критерий мужественности - это зарплата» (Tolson, 1977: 58).

Почти все свободные девушки среди наших информантов высказали намерение выйти замуж и иметь детей в качестве само собой разумеющегося желания в рамках их жизненного мира, не прибегая к каким-либо легитимирующим суждениям. Только одна из них упомянула о собственном текущем финансовом и социальном статусе и карьерных намерениях, остальные информанты или уже были замужем на момент интервью, или выражали общее намерение фразами, подобными этой: «как $b c e$, однажды и я хочу выйти замуж и завести детей». В сравнении с юношами брачные намерения девушек выражены в гораздо более неопределенной форме, скорее как цель-мечта, нежели реальный план, что может быть интерпретировано как убеждение в отсутствии возможности влиять на данный процесс. В патриархальном социальном мире, где брачное предложение традиционно исходит от мужчины, девушки по-прежнему надеются на удачу и судьбу, в то время как мужчины руководствуются более рациональными мотивами.

Функционирование гендерного порядка в культуре рабочего класса было проанализировано путем исследования взаимоотношений в родительской семье информантов. Методика анализа данных включала кодирование ответов на вопросы в блоке о родителях и семейной истории: «Кто был/является главой семьи? Как распределялись обязанности в семье? " В качестве переменных избраны следующие признаки: 
- социальный статус родителей на момент интервью, базирующийся на профессионально-должностном статусе и образовании (выше у отца / выше у матери / одинаковый статус);

- финансовое положение супругов и роль в обеспечении семьи (финансовое доминирование / финансовая зависимость);

- домашний труд (ответственность за большую часть рутинного труда / периодическое выполнение определенных видов домашнего труда);

- структура семьи (полная/неполная семья).

В зависимости от гендерного режима и микрополитик власти все семьи были традиционно разделены на три типа: патриархальная, әгалитарная и матриархальная. Аля анализа было отобрано 30 интервью (в одном из них вопрос не был озвучен ввиду смерти отца информанта). Семьи с признаками финансового или статусного доминирования одного из супругов были объединены в одну группу, также отдельно были выделены семьи матерей-одиночек.

Несмотря на то что почти в половине интервью информанты декларируют лидирующую роль отца в семье, только 7 из 30 семей можно назвать традиционно патриархальными. В половине случаев доминирование отца основано не на его финансовом или статусном превосходстве, а на коллективных стереотипах классовой культуры, требующих признания главенствующей роли мужчины вне зависимости от его реальной позиции. Кроме того, в половине рассмотренных случаев семьи информантов, отнесенные к патриархальному типу, на момент интервью относились к среднему классу или являлись кросс-классовыми. Чаще всего это семьи рабочих с восходящей мобильностью одного или обоих супругов; мать являлась домохозяйкой лишь в 2 случаях из 13 (см. таблицу).

ГЕНАЕРНЫЕ РЕЖИМЫ В СЕМЬЯХ РОАИТЕАЕЙ ИНФОРМАНТОВ БИОГРАФИЧЕСКОГО ИНТЕРВЬЮ (КОАИЧЕСТВО САУЧАЕВ)

GENDER REGIMES IN THE PARENTAL FAMILIES

OF THE BIOGRAPHICAL INTERVIEWS INFORMANTS (NUMBER OF

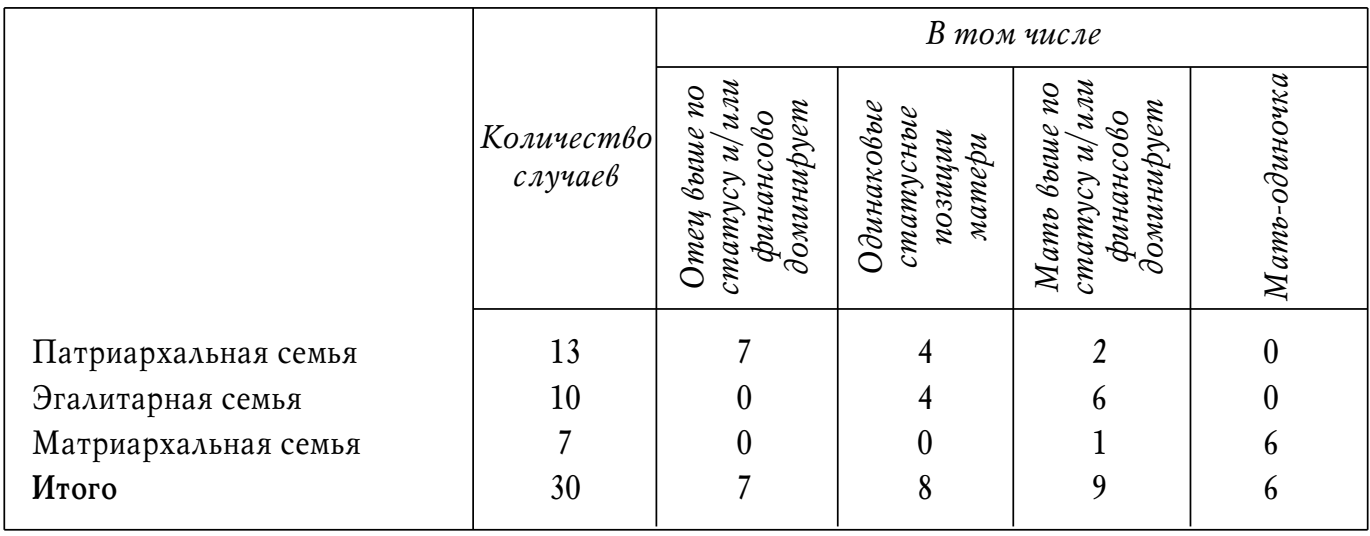

Аля большинства информантов из патриархальных семей характерен уверенный тон высказываний и использование риторических приемов, убеждающих собеседника в незыблемости данного гендерного режима ( "конечно, отеи», "естественно, отеи», "как у всех», "обычная семья» и т. А.). Наиболее ярко выражена подобная 
безусловная нормализация в суждениях девушек из благополучных семей, близких к среднему классу.

Алена, 24 года, администратор в магазине одежды: «Oтеи, основной заработок, основной доход у отиа. На маме, естественно, все домашние дела. Отеи большее количество время проводит на работе, но и параллельно еще занимается дачей, строит. В основном всем занимается мама дома - уборкой, готовкой, в общем, хозяйством. Отеи поздно приходит с работы, ложится перед телевизором, и все » (восходящая мобильность семьи из рабочего класса, отец - банковский специалист, мать медицинский регистратор).

Алина, 25 лет, администратор в салоне красоты: «Ну, наверное, как у всех, отеи. Мама у нас по дому все делает, так как она опять же домохозяйка, она все и успевает, и продукть даже купить. A папа больше работает» (семья среднего класса, отец - инженер в крупной нефтяной компании, мать - домохозяйка).

При әтом в патриархальных семьях участие отца в рутинной домашней работе интерпретируется как помощь женщине в исполнении ее обязанностей, даже если при этом социальный статус женщины выше.

Анастасия, 21 год, продавец в магазине одежды: «Мама Bыполняет работу по дому, папа тоже ей помогает с уборкой» (кросс-классовая семья, отец - установщик видеокамер и сигнализаций, мать - директор библиотеки).

Большинство работающих девушек из благополучных патриархальных семей не имеют карьерных амбиций и даже при их наличии готовы отказаться от них в случае удачного замужества и отсутствия необходимости зарабатывать на жизнь. Например, Александра, 24 год, продавец в магазине одежды, описывает жизненную цель-мечту следующим образом.

Информант: Ну, наверное, выйти замуж, просто родить ребенка и просто быть счастливым человеком и быть уверенной в том, что будушее обеспечено. Найти мужа, на которого можно положиться, будет зарабатььать, но чтобы работа не казалась ему трудной, чтобы не было проблем со здоровьем. Завести ребенка, сылрать свадьбу шикарную - какая женшина этого не хочет. Завести ребенка, а потом, может, и второго.

Интервьюер: В идеале хотела бы вообще не работать?

Информант: $А$.

Многочисленные повторы, присутствующие в высказывании, в совокупности с суждениями, легитимирующими нормативный гендерный порядок («какая женщина этого не хочет»), стремление оградить себя от жизненных проблем («чтобы работа не казалась ему трудной, чтобы не было проблем со здоровьем») и уйти с рутинной работы в семейную сферу («быть уверенной 8 том, что будущее обеспечено») лейтмотивы интервью большинства опрошенных нами девушек, занятых в сервисном секторе.

Негативные коннотации в описании патриархального режима власти и доминирования в семье были отмечены лишь в двух интервью, при этом одна семья распалась, а в другой социальный статус матери фактически выше, чем у отца. Так, Ксения, 22 год, кальянщик, в отличие от девушек из полных семей, описывает проживание с отцом следующим образом: «Отеч был полииейским, мама была домохозяйкой долгие годы, потому что отеи не хотел, чтобы она работала, потом все-таки согласился на то, чтоб она работала рядом с ним, секретарем... Сейчас глава семьи мама, потому что они с отиом в разводе, а до этого был отеи. Эмм... мама готови- 
ла, убирала, стирала, папа иногда мог забить гвоздь, по большой просьбе, а так в приниипе у него была только своя работа, а домашнего хозяйства он практически не касался».

Подобный опыт нашел свое отражение и в ее ответах на вопросы относительно собственных планов в семейной сфере. В высказываниях Ксении не наблюдается стремления к скорейшему исполнению гендерной роли матери и жены, в отличие от рассмотренных выше случаев девушек из благополучных патриархальных семей: "Я считаю, что рано выходить замуж не стоит, поэтому я в свободном плавании... Я пока не стремлюсь создавать полноченную семью, и планов на это пока нет ".

Юрий, 26 лет, рабочий железнодорожных путей, указывает на наличие семейных конфликтов из-за необходимости беспрекословного подчинения воле отца: «Отеи. Потому что как он скажет, так и было. В данный момент мы с ним можем конфликmовать. Так как я говорю так, а он по-другому» (отец - охранник, мать - заведующая рыбной базой). При этом собственная семейная жизнь у информанта не сложилась, женившись в 21 год, на момент интервью он уже был в разводе: «Hy, типа, ей не понравилось, что на квартире родителей жили, и то, что я на работе сутками торчал».

Рассмотрим далее семьи, которые на основании оценки информантов были отнесены к условно эгалитарному гендерному режиму. Полученные данные свидетельствуют о наличии двойных гендерных стандартов в оценке возможности быть главой семьи. Финансовое и статусное доминирование мужчины не вызывает сомнений в его лидерстве, однако, когда женщина занимает более высокую карьерную позицию или играет решающую роль в обеспечении семьи, информанты склонны говорить о "равноправии». Так, несмотря на реальное доминирование женщин в так называемых эгалитарных семьях (6 из 10 случаев), их позиции в иерархии не артикулируются в нарративах информантов. В смысловых структурах жизненного мира рабочей молодежи женщина не может играть роль лидера, ее задачей становится умелая игра в семейной властной микрополитике, направленная на сохранение видимости традиционного или эгалитарного гендерного порядка.

Ни один из наших информантов при наличии материальных и статусных оснований для доминирования мужчины в семье не охарактеризовал родительскую семью в терминах равенства и равноправия, безапелляционно признавая лидерство отца. В случаях же более успешной карьеры матери высказывания были не столь однозначны и зачастую противоречивы. Например, в случае Егора, 29 лет, менеджера по лизингу, статус семьи изменился в 1990-е гг. на кросс-классовый ввиду нисходящей мобильности отца (учитель физкультуры, рабочий на стройке, кочегар, пенсионер) и восходящей мобильности матери (учитель начальных классов, заместитель директора по учебно-воспитательной работе): «Отеч никогда не рвался вверх по карьерной лестниие, мама постепенно продвигалась и в итоге стала заместителем директора школь по учебно-воспитательной работе. Главой семьи вне дома всегда был отеи, а $b$ пределах квартиры мама. Обязанности всегда сами распределялись как-то между собой быстро, без криков, недовольства».

Ааже для условно әгалитарных семей с равным уровнем ответственности и перераспределением обязанностей в ответе на вопрос о «главе семьи» информанты чаще всего называли отца. Так, мы можем обратиться к интервью Аамира, 23 года, продавца в магазине бытовой техники.

Интервьюер: Кто у вас является главой семьи?

Информант: Omец. 
Интервьюер: И как распределяются обязанности в вашей семье?

Информант: Обязанности... сейчас на данньй момент раз мать работает, а отеч нет. Аома по домашним делам занимается он, ну, деньги, как бъ, в семью вношу я и мать, ну, брат еще, получается.

В интервью Аианы, 22 года, консультанта в банке, чьи родители обладают примерно одинаковом социальным статусом, наблюдаются два противоречащих друг другу высказывания в оценке семейного лидерства, а также твердая убежденность в необходимости сохранения гендерной роли женщины как «хранительницы очага».

Интервьюер: А кто является главой в вашей семье?

Информант: Папа.

Интервьюер: И как распределяются обязанности?

Информант: Ну, так как у нас и мама, и папа зарабатыьвают, оба находятся постоянно на работе, ну то есть я не скажу, что именно папа - глава семьи, наверное, такая демократическая семья в том смысле, ито если папа отдыхает, он спокойно может приготовить покушать, убраться, вот... Ну, тем не менее мама все равно старается создавать уют, так как она мама и женщина.

В интервью Руслана, 20 лет, посредника в сфере электроники, также присутствует метафора «демократии» и противоречие в оценке степени влияния каждого из родителей на принятие решений. С одной стороны, он говорит, что в его семье «все демократично, то есть нет такого, что там “я мужик, я здесь всем буду управлять, а ты женщина, слова не имеешь”, как-то все пятьдесят на пятьдесят", но при этом «все равно мнение отиа - оно доминирующее по серьезным таким вопросам». Аекларируемая «демократичность» его семьи является производной текущей ситуации, когда отец уже не может исполнять традиционную и желательную лидерскую роль в полной мере: "Сейчас у меня отец просто на пенсии, болеет, занимается, так скажем, хозяйством. Мать работает. А раньше, как в приниипе и у всех, отец зарабатььвал деньги, мать, она тоже работала, но работала, так, скажем, в удовольствие, уделяла времл дому, хозяйству, ну всем таким бытовым вещам» (отец - пенсионер, мать - учитель начальных классов).

Аоминирующую роль отца в принятии ключевых для «демократической» семьи решений отмечает и Антон, 26 лет, рабочий сцены: «У нас достаточно... как это... демократично, то есть мать всегда говорила, что муж - голова, жена - шея, то есть отеи принимает решения какие-то сложные, силовые, то есть денежные такие, ну, пробивные. А мать ему советует, как правильно сделать или как не делать. То есть семейный совет у нас также, где мы собираемся все, обсуждаем плюсы, минусы... Поэтому как бы главенствуюшего нету никого, на равных все». Распределение домашнего труда при этом традиционное: «Отеи уделял внимания работе или обустройству дома, мать занималась нами, воспитанием, учебой, ну, как говорится, моральньмм воспитанием, то есть чтобы людьми выросли, и слежением, то есть, там, не загулял, не забухал...» (отец - водитель, мать - продавец).

Аналогично описывает родительскую семью Евгений, 26 лет, повар: «Главной бaбушка была. Мамина мама с нами жила, всеми нами командовала. Потом уехала $к$ себе в деревню - главной мама стала... а может, и папа... Сложный вопрос. Равноправие, наверное. Ну, папа зарабатывал всегда больше - добытчик типа. А мама Все остальные вопросы решала: что в доме надо сделать, куда мы все поедем на каникуль и в выходные. Такая классическая обычнал семья. Но папа всегда к маминому мнению прислушивается. Но и мама папе наперекор редко что делает - советы они семей- 
ные устраивают. Мь тоже в этих советах с сестрой раньше принимали участие, когда с родителями жили» (отец - сварщик, мать - бывший инженер, пенсионер).

Очевидно, что в большинстве случаев декларирования семейного равноправия информанты сохраняют представление о доминирующей роли мужчины, оставляя женщине «право голоса» и возможность влиять на принятие решений в коллективном обсуждении. Перераспределение домашнего труда трактуется как вынужденная мера, связанная с обстоятельствами, в силу которых отец не может в полной мере выполнять свою гендерную роль в семье ввиду болезни, выхода на пенсию или карьерных неудач. Идеал эгалитарной семьи описывается с помощью метафоры «демократия» и образа «семейный совет», где «народ» (жена и дети) имеют возможность влиять на решение власти (отца).

Женское лидерство всегда имеет негативные коннотации в нарративах информантов. В нашей выборке встретился только один случай, где главой полной семьи признается мать.

Татьяна, 21 год, гардеробщик: "...она выполняет большую часть обязанностей, она обеспечивает нашу семью и в приниипе делает то, что обьчно делают мужчинь в семьях... әто связано с тем, что он [отец] предприниматель и он занимается своей деятельностью как хобби, а не как средством... заработка или получения денег, прибыли» (отец - индивидуальный предприниматель, мать - экономист-бухгалтер).

В остальных наблюдениях доминирующая роль женщины обусловлена распадом семьи. Многие информанты подчеркивают, что и во время жизни с отцом мать играла лидирующую роль, что не исключает возможности интерпретировать факт неспособности отца быть главой семьи как одно из оснований ее распада. Стоит отметить отличие используемых для описания женского лидерства языковых средств: нарратив о рассмотренных выше типах семей включал в себя развернутые ответы и описания, в случае же семей с женским доминированием информанты предпочитали лишь констатировать факт сложившейся вынужденной ситуации, не желая обсуждать детали. В пример можно привести ответ Станислава, 25 лет, оператора по приему цветного металла.

Интервьюер: Можно сказать, что по большому счету мама была главой семьи?

Информант: Аа. Решала.

Заложенная в детстве матриархальная модель семейных взаимоотношений оказала влияние и на восприятие данным информантом собственной жизни, профессиональных и карьерных перспектив. Он признается, что мечтает о полной семье в качестве мотивации для профессионального и карьерного роста. Одинокому молодому человеку «не для кого стараться», а женщина рядом, по его словам, могла бы его вдохновить на жизненные достижения.

Информант: Нету второй половинки, и нету стимула, я так считаю, в жизни... мне кажется, что я на месте стою и дальше не продвигаюсь... ито никто меня не толкает на какие-то дальнейшие поступки.

Интервьюер: Это чья задача, по-твоему? Толкать тебя на поступки?

Информант: $М$-м-м... Так-то по большей части все от меня зависит. Но я б хотел бы, чтобы был рядом человек, который бы меня... как это правильно сказать, мотивировал. Стимул мне придавал, то есть смьсл жизни.

Мы не обнаружили явного тренда на преобладание того или иного типа родительской семьи и сферы занятости информанта. Семьи как представителей традиционного рабочего класса, так и работников сервиса относятся ко всем трем выделенным типам. При этом, однако, есть различие в восприятии традиционных гендерных ро- 
лей: молодые люди, занятые в сервисной сфере, в меньшей степени демонстрируют качества, ассоциирующиеся с гегемонной маскулинностью. Юноши, описывающие гендерный режим родительской семьи как эгалитарный, не скрывают, что зачастую ориентируются на мнение женщин и принимают их помощь в вопросах образования и трудоустройства.

Руслан, 20 лет, посредник по продаже электроники: «У меня просто мать зашла на сайт, нашла техникум, ткнула на ссьлку, и я поступил, вот и все, то есть не бьло никакого выбора вообще».

Амитрий, 27 лет, бариста: «Занималась подбором вакансий по определенньм критериям моя девушка с помошью популярных сайтов. Периоды безработичь бьли, которые сопровождались угрызениями совести (опускает взгляд). Выход из ситуачии - пошел на работу, переступив через лень и не поддавиись диванному искушению ».

Александр, 28 лет, менеджер по продажам автомобилей: «После армии я хотел пойти торговать кирпичами и иементом в одну из сетей, торгуюшую стройматериалами в нашем городе. Но когда я поделился этим с хорошей знакомой семьи, она посмотрела на меня и сказала, что лучше работать в чистом деловом костюме, чем в пьльной рабочей форме, и я с әтим согласился. Устроился я так в огромный тюменский холдинг и без высшего образования».

\section{ЗАКАЮЧЕНИЕ}

Таким образом, анализ качественных данных демонстрирует, что консерватизм и патриархальные семейные установки, которые приписывают рабочему классу в массовой культуре, оставаясь доминирующими в сознании молодежи, тем не менее имеют мало общего с реальной жизненной ситуацией наших информантов. Ввиду крайне низкого дохода большинства рабочих семей классическая патриархальная модель семьи (мужчина - добытчик, жена - домохозяйка) в российских реалиях доступна только представителям среднего класса. Бедность, карьерные неудачи или отсутствие амбиций, рано возникающие серьезные проблемы мужчин со здоровьем обусловливают необходимость перераспределения гендерных ролей в семье, превращая женщину в «кормильца» и лидера семьи. В случае мужского доминирования в родительской семье информанты охотно и подробно рассказывают об этом, ситуации же женского лидерства оцениваются как вынужденные и трактуются в категориях семейного «равноправия» либо артикулируются в крайне сжатой форме.

При одинаковом статусе мужчины и женщины рабочего класса, занятые рутинным трудом, по-прежнему обладают далеко не равными финансовыми возможностями: оплата труда в сервисном секторе гораздо ниже, чем в промышленном, и две трети работников сферы услуг в России по-прежнему составляют женщины. Экономические факторы закрепляют условия для воспроизводства практик структурного доминирования мужчин в семейной сфере, сохранение позитивной нормативной установки относительно паттерна мужчины-добытчика, обладающего властью в семье на основании контроля над экономическими ресурсами. Аевушки из сервисного сектора стремятся к патриархальной модели семьи, демонстрируя желание закрепиться на позиции среднего класса посредством удачного замужества и, по возможности, не работать. Юноши также поддерживают патриархальную модель как нормативный ориентир, однако их собственный жизненный опыт и опыт родительских семей далеко не всегда соответствует идеально-типической конструкции доминирующего гендерного порядка. 


\section{СПИСОК АИТЕРАТУРЫ}

Вольфсон, С. Я. (1929) Социология брака и семьи. Минск : БГУ. 472 с.

Гаврилюк, Т. В. (2018) Гендерная проблематика в зарубежном классовом анализе: динамика теоретических подходов // Вестник МУ. Серия 18. Социология и политология. Т. 24. № 4. C. $26-40$.

Гаврилюк, Т. В., Бочаров, В. Ю. (2018) Интерсекциональность как способ концептуализации гендерного и классового неравенства // Журнал исследований социальной политики. № 16 (3). C. 537-545.

Парсонс, Т. (2002) Аналитический подход к теории социальной стратификации // Парсонс Т. О структуре социального действия. 2-е изд. М. : Академический проект. 880 с. С. 354-380.

Pro Тело. Молодежный контекст : сб. статей (2013) / под ред. Е. Омельченко, Н. Нартовой. СПб. : Алетейя. 288 с.

Augustyn, M. B., Jackson, D. B. (2017) An intersectional look at the "rush to adulthood": Considering the role of gender, race and SES in the link between precocious transitions and adult antisocial behavior [Электронный pecypc] // Youth \& Society. August 14. URL: https:// journals.sagepub.com/doi/10.1177/0044118X17725245 (дата обращения: 28.12.2018). DOI: 10.1177/ $0044118 X 17725245$

Bird, K., Kruger, H. (2005) The secret of transition: The interplay of complexity and reduction in life course analysis // Towards an Interdisciplinary Perspective on the Life Course. Advances in Life Course Research, Vol. 10, JAI Press. Pp. 173-194.

Britten, N., Heath, A. (1983) Women, men and social class // Gender, Class and Work / E. Garmarnikov et al. London : Heinemann. 241 p. Pp. 46-60.

Goldthorpe, J. H. (1983) Women and class analysis: in defence of the conventional view // Sociology. № 17 (4). P. 465-488.

Delphy, C. (1984) Close to home: a materialist analysis of women's oppression. London : Hutchinson. 237 p.

Falk, S., Weymann, A. (2002) Social change, the life course, and socialization: biographies of labor market entrants after unification // Advances in Life Course Research. Vol. 7. P. 501-526.

Meier, A., Allen, G. (2008) Intimate relationship development during the transition to adulthood: Differences by social class // New Directions for Child and Adolescent Development. Vol. 2008, Issue 119. Special Issue: Social Class and Transitions to Adulthood. P. 25-39.

Penman-Aguilar, A., Carter, M., Snead, M. C., Kourtis, A. P. (2013) Socioeconomic disadvantage as a social determinant of teen childbearing in the U. S. // Public Health Reports. № 128 (2 Suppl. 1). P. 5-22.

Settersten, R. A. Jr., Gannon, L. (2005) Structure, agency and space between: on the challenges and contradictions of a blended view of the life course // Towards an Interdisciplinary Perspective on the Life Course. Advances in Life Course Research. Vol. 10. P. 35-55.

Tolson, A. (1977) The Limits of Masculinity. London: Tavistock. 158 p.

Vanke, A. (2014) The corporeality of working-class men in labour regimes and the private sphere. Summary // Laboratorium. №6 (1). P. 154-158.

Аата поступления: 08.01.2019 2.

\section{REPRESENTATION OF THE WORKING CLASS GENDER REGIMES IN THE BIOGRAPHICAL NARRATIVES OF YOUTH \\ T. V. GAVRILYUK \\ TYUMEN INDUSTRIAL UNIVERSITY}

The article substantiates the necessity to update the study of gender inequality with regard to class status. The subject domain of the research is to examine gender regimes which exist in everyday culture of the working class in modern Russia by means of analysis of their representation in young people's biographical narratives. The research is focused on the intergenerational transmission of gender 
normative patterns, micro-policy of power and domination in working class families, as well as forms of their discursive production and legitimization. The empirical base of the research is represented by 31 biographical interviews with the new working class representatives aged from 21 to 33, living in Tyumen and working in the field of industry, technical maintenance and customer service. The interviews were conducted from February till August 2018. Reflexive analysis based on the categorical field of phenomenology and social constructivism, as well as data coding and quantification were used as the main research tools.

It was established that the normative pattern of the male breadwinner, enjoying power in the family on the basis of his control over the economic resources, is still domineering among Russian young men, but their life experience and the experience of their parent families do not always correspond to the ideal-typical construction of the dominant gender order. Girls from the service sector are also striving for the patriarchal family model, demonstrating a desire to gain a foothold in the middle class through successful marriage. By studying the gender regimes of the informants' parental families, it was discovered that the financial and status dominance of the man raises no doubts about his leadership. When the woman gains a higher status or plays a crucial role in providing for the family, informants tend to talk about "equality" in the family. In families with a matriarchal regime, the situation of female leadership has been assessed as forced. In the semantic structures of the working class daily life, the woman cannot play the role of a leader; her task is to become a skillful performer in the family's micropolitical power game, aimed at preserving the appearance of the traditional or egalitarian gender order.

Keywords: working class; youth; working class youth; patriarchy; gender; gender regime; gender inequality

\section{REFERENCES}

Volfson, S. Y. (1929) Sotsiologia braka i semi’ i. Minsk, BGU. 472 p. (In Russ.)

Gavrilyuk, T. V. (2018) Gendernaya problematika v zarubejnom klassovom analize. Moscow State University Bulletin. Series 18. Sociology and Political Science, vol. 24, no. 4, pp. 26-40. (In Russ.)

Gavrilyuk, T. V. and Bocharov, V. U. (2018) Intersektsional'nost' kak sposob kontseptualizatsii gendernogo i klassovogo neravenstva. The Journal of Social Policy Studies, no 16 (3), pp. 537-545. (In Russ.)

Parsons, T. (2002) Analiticheskij podbod k teorii social' noj stratifikacii. In T. Parsons. O strukture social' nogo dejstvija. 2nd ed. Moscow, Akademicheskij Proekt. 880 p. Pp. 354-380. (In Russ.)

Pro Telo. Molodejnii kontekst. Sbornik statei (2013) / E. Omel'chenko, N. Nartova (eds). St. Petersburg, Aleteia. 288 p. (In Russ.)

Augustyn, M. B. and Jackson, D. B. (2017) An intersectional look at the "rush to adulthood": Considering the role of gender, race and SES in the link between precocious transitions and adult antisocial behavior. Youth \& Society [online] Available at: https://doi.org/10.1177/0044118X17725245 (accessed 28.12.2018).

Bird, K. and Kruger, H. (2005) The secret of transition: The interplay of complexity and reduction in life course analysis. In: Towards an Interdisciplinary Perspective on the Life Course. Advances in Life Course Research, Vol. 10, JAI Press. Pp. 173-194.

Britten, N. and Heath, A. (1983) Women, men and social class. In: Gender, Class and Work. E. Garmarnikov et al. (eds.) London, Heinemann. 241 p. Pp. 46-60.

Goldthorpe, J. H. (1983) Women and class analysis: in defence of the conventional view. Sociology, no. 17 (4), pp. 465-488.

Delphy, C. (1984) Close to home: a materialist analysis of women's oppression. London, Hutchinson. 237 p.

Falk, S. and Weymann, A. (2002) Social change, the life course, and socialization: biographies of labor market entrants after unification. Advances in Life Course Research, vol. 7, pp. 501-526.

Meier, A. and Allen, G. (2008) Intimate relationship development during the transition to adulthood: Differences by social class. New Directions for Child and Adolescent Development. Issue 119. Special Issue: Social Class and Transitions to Adulthood. Pp. 25-39. 
Penman-Aguilar, A., Carter, M., Snead, M. C. and Kourtis, A. P. (2013) Socioeconomic disadvantage as a social determinant of teen childbearing in the U. S. In: Public Health Reports, no. 128 (2 Suppl. 1), pp. 5-22.

Settersten, R. A. Jr. and Gannon, L. (2005) Structure, agency and space between: on the challenges and contradictions of a blended view of the life course. In: Towards an Interdisciplinary Perspective on the Life Course. Advances in Life Course Research, vol. 10, pp. 35-55.

Tolson, A. (1977) The Limits of Masculinity. London, Tavistock. 158 p.

Vanke, A. (2014) The corporeality of working-class men in labour regimes and the private sphere. Summary. Laboratorium, no. 6 (1), pp. 154-158.

Submission date: 08.01.2019.

Гаврилюк Татьяна Владимировна — кандидат социологических наук, доцент, старший научный сотрудник Центра перспективных исследований и инновационных разработок Тюменского индустриального университета. Адрес: 625000, Россия, г. Тюмень, ул. Володарского, д. 38. Тел.: +7 (963) 453-39-71. Эл. адрес: tv_gavrilyuk@mail.ru

Gavrilyuk Tatyana Vladimirovna, Candidate of Sociology, Associate Professor, Senior Research Fellow, Centre for Advanced Research and Innovation, Tyumen Industrial University. Postal address: 38, Volodarskogo St., Tyumen, Russian Federation, 625000. Tel.: +7 (963) 453-39-71. E-mail: tv_gavrilyuk@mail.ru 